\title{
EXPORTS, FOREIGN DIRECT INVESTMENT AND ECONOMIC GROWTH: EMPIRICAL EVIDENCE FROM MALAYSIA (1971-2013)
}

\author{
${ }^{1}$ Muhammad Haseeb, ${ }^{2}$ Nira Hariyatie Hartani \\ ${ }^{3}$ Nor' Aznin Abu Bakar, ${ }^{3}$ Muhammad Azam and ${ }^{3}$ Sallahuddin Hassan \\ ${ }^{1,3}$ Department of Economics, School of Economics Finance and Banking, \\ College of Business Universiti Utara Malaysia, Malaysia \\ ${ }^{2}$ School of Government, COLGIS, Universiti Utara Malaysia, Malaysia
}

Received 2014-01-05; Revised 2014-02-23; Accepted 2014-04-15

\begin{abstract}
The main objective of this study is to empirically investigate the relationship between exports, Foreign Direct Investment (FDI) and the economic growth in Malaysia. Records of annual time series data from the year 1971 till 2013 have been utilized for this purpose. Upon testing the data for stationarity, the Auto Regressive Distributed Lag (ARDL) model has been applied for the purpose of empirical investigation. The empirical results indicate that the productivity factor and externality effect of exports on the non-export sector are found to be statistically, positively significant, with the exports also having a positive impact on the economic growth and FDI of the country. The results support Exports Led Growth (ELG) and FDI-Led economic Growth (FLG) in Malaysia. The finding further suggests that Malaysia should continuous pursue exports promotion and a liberal investment economic policy in order to maintain and bolster overall economic growth.
\end{abstract}

Keywords: Exports, FDI, Economic Growth, ARDL, Malaysia

\section{INTRODUCTION}

Exports and FDI are considered as main determinants of high economic growth in Southeast Asian countries (Shawa and Yao, 2013; Eryigit, 2012). The prevailing development strategies have placeddue emphasis on both export growth and in attracting high levels of FDI. Shouldthis outward-oriented approach really do grow faster than expected, one would expect this to be a consequence of exports imparting dynamism to the economy as a whole and through FDI stimulation further increasing total investment in an economy or, at least, not reducing it (Liangshu, 2007).

The main achievement of Malaysia's export-oriented industrialization is the remarkable increase of Malaysia's export and FDI inflow. Although it increased in absolute terms from an average of RM 838 million in 1970s to an average of RM2351 million, RM12184 million,
RM16592 and RM35453 million in 1980s, 1990s, 2000s and 2010-2013 respectively, those flows were very fluctuating in nature. With regards to the share of FDI inflow throughout the world, Malaysia has share of 0.65 , 0.74 and $0.77 \%$ in the years 2010, 2011 and 2012 respectively. While, in Asian countries Malaysia have share of 2.29, 2.72 and $3.99 \%$ in 2010, 2011 and 2012 accordingly. However, in ASEAN countries Malaysia have share of $9.89,10.43$ and $10.65 \%$ for the year 2010 , 2011 and 2012 in order. Moreover, in statistics of FDI inflow, Malaysia ranked 3rd among South-East Asian countries and 8th among Asian countries for the year 2013 (WTO, 2013).The Malaysian economy has grown rapidly over the past decades. From the period between 1971 and 2013, the real GDP has grown on an average of $6.32 \%$ per annum. Malaysian per capita income (current GNP per capita) rose from US\$380 in 1970 to US\$10,304 in 2013 (WB, 2013).

Correspondence Author: Muhammad Haseeb, Department of Economics, School of Economics Finance and Banking, College of Business, University Utara Malaysia (UUM), Sintok 06010 Kedah Malaysia Tel: +60172957409 
Exports performance by developing countries is highly diverse in nature. Its pattern differs significantly by country and region; over time, they are fluctuating at different rates and in different directions. In the case of Malaysia, the ratio of total export to GDP has increased significantly from $38 \%$ in 1971 to $54.84 \%$ in 1980 and $83.15 \%$ in 1995 before declining slightly to $78.4 \%$ in 1997. However, this percentage showed an increase during the following years to reach $87.46 \%$ in 2013. A composition change has been witnessed in the exports structure, changingmarkedly over the last 42 years; primary commodity exports constituted $79.1 \%$ of total exports in 1971 (Bank Negara Malaysia, Monthly Statistical Bulletin, 1972).

This study investigates the inherent dynamic relationships betweenthe economic growth of Malaysia and the related macroeconomic variables, namely FDI and exports; describingtheir relationship and determining their relative significance in influencing real output during the previous 42 years. In general, this study will contribute to the existing body of economic literature and development economics, in a number of ways. Firstly, it will facilitate a survey and offer distinctions between major views on the relationship between FDI, exports and economic growth. Secondly, a significant portion of empirical studies being conducted are either on the relationship between economic growth and export or on the links between growth and FDI. Finally, it attempts to provide empirical contributions to economic growth, mainly by undertaking developments in econometric tools in analyzing properties of the time series data such as unit root test and ARDL to cointegration for empirical investigation.

This study is structured as follows; Section 1 above provides an introduction of the study, section 2 presents the related literature review, section 3 provides the corresponding theoretical background, methodology, model specification and data source of the study, section 4 explains the empirical results and finally, section 5 reports the conclusion of the study and its policy implication.

\section{LITERATURE REVIEW}

The links between exports, FDI and economic growth in both developed and developing countries is an issue that continues to be of substantial theoretical and empirical interest; cross-country trade, capital flow and interpreting the importance of these activities towards economic growth lie at the key of the debate on economic growth (Abdullahi et al., 2013; Azam et al., 2013; Wei and Wang, 2012; Mishara, 2011). In the literature with regards to both FDI and economic growth, there are several channels through which foreign investments are linked to growth in developing countries. The role played by inward FDI in export performance of developing countries is one of the intensely debated issues in the literature of development economics (Teodora and Marinela, 2011; Elbeydi et al., 2010).

Mahadevan (2007) investigated the notion that FDI inflows in 14 transition economies of central and Eastern Europe during the period of 1993 to 2006 have improved the export performance. In an effort to estimate this relationship, the author used the linear unobserved effects panel data model. The results suggested that, along with real effective exchange rates and development of export markets, FDI has been a significant determinant of exports performance for the entire sample.

Development economists, specifically with relation to Malaysia's economy, have determinedan increased correlationin the relationship between exports expansion and economic growth. They also investigated the effects of export expansion upon the economy (Ging, 2009; Furuoka, 2009). Sulaiman and Saad (2009) examined the links between export and economic growth by using quarterly time series and OLS during the years 1967 to 2009. The corresponding results exhibit strong evidence of causal relationships running from export series to economic growth. The sum of the coefficient of causal variables also shows positive signs which support the ELG strategy for pursuing economic growth in Malaysia.

Baharumshah and Almasaied (2009) reexamined the relationship between exports growth and economic growth using the annual data for the years 1963 to 2009 and appliedcointegration and error correction modeling techniques. The results reported here provide strong empirical support for bidirectional growth between exports and output, besides a positive long-run relationship between two variables. Furthermore, Azam et al. (2013) found that FDI had a positive impact on the economic growth of five South and South East Asian countries during the period from 1985 to 2011. Mohamed et al. (2013) investigated the ELG hypothesis in the case of Malaysia. They used quarterly data from years 1964 till 2010 and applied cointegration. The results of the regression analysis indicate a positive causality between exports and economic growth. 


\section{MATERIALS AND METHODS}

This study based on Feder and O'Mara (1982) and can write as follows have follow:

$G D P=f(F D I, D I, E X P, G L)$

Where:

$G D P=$ Gross domestic investment,

$F D I=$ Foreign direct investment,

$E X P=$ Exports and

$G L=$ Growth of labor .

So, by taking natural $\log (\ln )$ Equation 1 has been transformed in to Equation 2:

$$
\begin{aligned}
& \ln G D P_{t}=\beta_{0}+\beta_{1} \ln F D I_{t}+ \\
& \beta_{2} \ln D I_{t}+\beta_{3} \ln E X P_{t}+\beta_{4} \ln G L_{t}+\varepsilon_{t}
\end{aligned}
$$

Where:

$\beta_{0}=$ Intercept,

$\left.\beta_{i}=\mathrm{i}=1,2,3,4\right)$ are coefficients and

$\varepsilon_{t}=$ An error term.

Determining causality is an important component of modeling economic relationship. Further to this, the ARDL Approach was used for the purpose of checkingcointegration among the variables. Using the Unit Root test, cointegration (by ARDL approach) and error correction model techniques is not entirely new to research studies carried out around the world. However, grouping the variables, namely FDI and exports and testing their significance to GDP in the Malaysian context is a new contribution of this study.

\subsection{Data Sources}

Annual time series data spanning from 1971 to 2013 are used. The data are obtained from the Bulletin of Bank Negara Malaysia, Economic Reports published by the Ministry of Finance and the International Financial Statistic yearbook published by the International Monetary Fund (IMF).

\subsection{Empirical Results and Analysis}

\subsubsection{The Unit Root Test}

To test the order of integration of the variable, this study has used the standard test for unit root, namely the Augmented Dickey-Fuller (ADF) test. The results in Table 1 containing of ADF test indicate that all the variables are stationary at level.

\subsection{Cointegration}

The primary focus of this study is to explore the long run effects of both FDI and exports on economic growth. Thus, it is an axiomatic task to test for the cointegration of variables. This study employs ARDL or bound test procedure proposed by Pesaran et al. (2001) to test for the cointegrating relationships. The bounds testing procedure involves three stages. The first stage is to establish the existence of a long run relationship. Let the Equation 1 this is based on estimating error correction models by taking GDY(Y) as a dependent variable and the following ECM models are constructed:

$$
\begin{aligned}
& \Delta G D P_{t}=\alpha_{0}+ \\
& \sum_{i=1}^{n} b_{i} \Delta G D P_{t-i}+\sum_{i=0}^{n} c_{i} \Delta F D I_{t-i}+\sum_{i=0}^{n} d_{i} \Delta D I_{t-i}+\sum_{i=0}^{n} e_{i} \Delta G L_{t-i} \\
& +\lambda_{1} G D P_{t-1}+\lambda_{2} F D I_{t-1}+\lambda_{3} D I_{t-1}+\lambda_{4} G L_{t-1}+\varepsilon_{t}
\end{aligned}
$$

The second step is to compute the F-test for testing the existence of a long-run relationship. The null hypothesis for no cointegration amongst the variables in Equation 3 is:

$$
H_{0}: \lambda_{1}=\lambda_{2}=\lambda_{3}=\lambda_{4}=0
$$

(There is no long-run relationship) against the alternative hypothesis that not all of these coefficient are equal to zero:

$$
H_{1}: \lambda_{1} \neq 0, \lambda_{2} \neq 0, \lambda_{3} \neq 0, \lambda_{4} \neq 0
$$

(There is a long-run relationship). The third step is compare the F-test computed in the second step with the upper bound and lower 90, 95 or $99 \%$ critical value bounds. Narayan (2004) provided two sets of critical values bound which are reported in Table 2. One set assuming that all the regressors are $\mathrm{I}(1)$ and other set assuming that they are all $\mathrm{I}(0)$.

\subsection{The Long-Run Relationship Results}

Having found a long-run (cointegration), Equation 1 estimated in the next proceeded using the following $\operatorname{ARDL}\left(\mathrm{q}_{1}, \mathrm{q}_{2}, \mathrm{q}_{3}, \mathrm{q}_{4}\right)$ models Equation 4:

$$
\begin{aligned}
& G D P_{t}=\alpha_{0} \\
& +\sum_{i=1}^{q_{1}} \alpha_{1} G D P_{t-i}+\sum_{i=0}^{q_{2}} \sum_{i=0}^{q_{3}} \alpha_{3} D D I_{t-i}+
\end{aligned}
$$

All variables are previously defined. The results of estimated long-run coefficients are reported in Table 3. 
Table 1. Results of ADF unit root test

\begin{tabular}{|c|c|c|c|c|c|}
\hline \multirow[b]{2}{*}{ Variables } & \multicolumn{2}{|l|}{ Level } & \multicolumn{2}{|c|}{ First difference } & \multirow[b]{2}{*}{ Results } \\
\hline & Intercept & Intercept and trend & Intercept & Intercept and trend & \\
\hline GDP & $2.518 *$ & -0.967 & -4.270 & -5.2260 & $\mathrm{I}(0)$ \\
\hline FDI & -1.454 & $-3.019 *$ & -8.660 & -8.5050 & $\mathrm{I}(0)$ \\
\hline DI & -1.984 & $-3.022 *$ & -5.233 & -5.2430 & $\mathrm{I}(0)$ \\
\hline EXP & -1.775 & -1.135 & $-3.924 *$ & -5.4590 & $\mathrm{I}(1)$ \\
\hline GL & $1.233^{*}$ & -1.829 & -6.135 & -6.5370 & $\mathrm{I}(0)$ \\
\hline
\end{tabular}

Note: *Denotes significant level based on the McKinnon critical value

Table 2. F-tests for cointegration

\begin{tabular}{llllll}
\hline & $90 \%$ & & & & $99 \%$ \\
Critical value* & ------- & $95 \%$ & $-1(1)$ & $\mathrm{I}(0)$ & $\mathrm{I}(1)$ \\
\hline $5 * *$ & $\mathrm{I}(0)$ & $\mathrm{I}(1)$ & $\mathrm{I}(0)$ & 3.960 & 5.603 \\
Calculated value & 2.361 & 3.433 & 2.826 & 4.049 & \\
\hline
\end{tabular}

Notes: *The critical value bounds are from Table $\mathrm{F}$, restricted intercept and no trend in Narayan 2004. ** No. of regressors, *** significant at the $10 \%$

Table 3. Estimated long run results

\begin{tabular}{|c|c|c|c|c|c|}
\hline Regressors & Coefficient & t-Ratio & Regressors & Coefficient & t-Ratio \\
\hline $\mathrm{FDI}_{\mathrm{t}}$ & 0.499 & $3.213^{*}$ & $\mathrm{DI}_{\mathrm{t}}$ & 0.206 & $13.240 *$ \\
\hline $\mathrm{EXP}_{t}$ & 0.178 & $3.929 *$ & $\mathrm{GL}_{\mathrm{t}}$ & 1.511 & $6.171^{*}$ \\
\hline $\mathrm{C}$ & 0.915 & 1.239 & $\delta$ & 1.120 & $\ldots \ldots$ \\
\hline
\end{tabular}

Notes: *Denoted significance at the $1 \%$

The results indicate that Malaysia's exports are directly related to its respective GDP. All coefficients are highly statistically significant. In addition to this, the results also show that for a one percent increase in export production, there is an increase in the GDP by $0.39 \%$. Moreover, marginal productivity of domestic investment in the non-export sector has significant effects on GDP and a one percent increase in domestic investment leads to a $0.20 \%$ increase in GDP. The impact of labor force is also positive and therefore, this result are in tune with both the theory and empirical finding, specifically that labor force in Malaysia promotes economic growth.

\subsection{Short-Run Error Correction Model}

The results of ECM are shown in Table 4. The results indicate that after controlling for other variables, the change in FDI does have an immediate effect on GDP. Moreover, the results show that the expected negative connotation of ECM is highly significant in both models. This confirms once again the existence of cointegration relationship among the variables.

The coefficient of $\mathrm{ECM}_{\mathrm{t}-1}$ are equal to (-0.683) for this model and implies that deviation from the longrun growth rate in GDP are corrected by $0.68 \%$ in the model over the following year. In other words, once the economy is exposed to shock, it will take a short time to recover.

\subsection{Diagnostic Test}

The robustness of the model has been confirmed by diagnostic tests. As shown in Table 5; both models generally pass all diagnostic tests.

\subsection{Stability Test}

The Cumulative Sum (CUSUM) and the Cumulative Sum of Squares (CUSUMSQ) graphical representations indicate the absence of any instability of the coefficient as the plots of these statistics remains within the critical bound of the $5 \%$ significancelevel. Hence, these statistics confirm the stability of long-run coefficients of the GDP function in the model. 
Muhammad Haseeb et al. / American Journal of Applied Sciences 11 (6): 1010-1015, 2014

Table 4. Estimated Short-Run Error Correction Model ECM-ARDL (1, 0, 2, 2, 0, 0)

\begin{tabular}{|c|c|c|c|c|c|}
\hline Regressors & Coefficient & t-Ratio & Regressors & Coefficient & t-Ratio \\
\hline$\Delta \mathrm{EXP}_{\mathrm{t}}$ & 0.090 & $4.171 *$ & $\Delta \mathrm{DI}_{\mathrm{t}}$ & 0.090 & $9.158^{*}$ \\
\hline$\Delta \mathrm{FDI}_{\mathrm{t}}$ & 0.197 & $5.460 *$ & $\Delta \mathrm{GL}_{\mathrm{t}}$ & 0.791 & $2.851 *$ \\
\hline$\Delta \mathrm{FDI}_{\mathrm{t}-1}$ & -0.069 & -0.730 & $\Delta \mathrm{GL}_{\mathrm{t}-1}$ & 0.786 & $1.841^{*}$ \\
\hline Intercept & 2.870 & $3.197 *$ & Adjusted R2 0.885 & & \\
\hline ECTt-1 & -0.683 & $-7.197 *$ & F-statistic $\quad 29.301$ & & \\
\hline
\end{tabular}

$(*)$ denotes significance according to tabulated t-values $(+1.96,-1.96)$

Table 5. Results of diagnostic tests

Model (I) ARDL (2, 3, 0, 4, 4)

\begin{tabular}{lllll} 
Test & $\mathrm{H}_{0}$ & Statistic & p-value & Decision \\
\hline $\mathrm{SC}$ & There is no serial correlation in the residual & $\mathrm{X}^{2}=0.1033$ & 0.748 & fail to reject $\mathrm{H}_{0}$ \\
$\mathrm{HE}$ & There is no autoregressive conditional heterscedasticity. & $\mathrm{X}^{2}=3.518$ & 0.862 & fail to reject $\mathrm{H}_{0}$ \\
$\mathrm{NO}$ & Normal distribution & $\mathrm{JB}=0.751$ & 0.687 & fail to reject $\mathrm{H}_{0}$ \\
$\mathrm{FF}$ & Absence of model misspecification & $\mathrm{X} 2=7.937$ & 0.932 & fail to reject $\mathrm{H}_{0}$ \\
\hline
\end{tabular}

\section{CONCLUSION}

The main aim of this study is to investigate the inherent dynamic relationship between the economic growth of Malaysia and its macroeconomic variables, namely FDI and exports. For the purposeof empirical investigation, time series data from the years 1971 to 2013 was used. The results revealed that the time series for two models achieved stationarity after first difference. These results were obtained though the utilization of ADF unit root tests. In addition, the ARDL cointegration test shows that there is a strong correlation between Malaysia's growth performance, exports and FDI. Both exports and FDI gave positive correlation with the growth of GDP, as suggested by some theories. As a result, the prevailing export promotion industrialization policy has proven to be an effective development strategy. Thus, it should be continuous implemented by the government to achieve favorable growth rates. The empirical findings also indicate the existence of FLG relations. FLG does indeed stimulate growth through improvements in physical capital accumulation. Hence, FDI is viewed as a catalyst for domestic growth and technological progress in Malaysia. Finally, the results also show that there is export-oriented FDI linkage in Malaysia. This basically means that the inflows of capital into the economy in influenced by the growth rate of exports. Hence, drawing fromthe results of the study conducted, Malaysia should focus on both export and FDI to boost the country's economic growth.

\section{REFERENCES}

Abdullahi, Y., A. Sokoto and S. Safiyanu, 2013. Analysis of the relationship between foreign trade and economic growth in Africa. Econom. Finance Rev., 3: 1-10.

Azam, M., S. Hassan and Khairuzzaman, 2013. Corruption, workers remittances, FDI and economic growth in five South and South East Asian Countries: A panel data approach. Middle-East J. Sci. Res., 15: 184-190.

Baharumshah, A. and S.W. Almasaied, 2009. Foreign direct investment and economic growth in Malaysia: Interactions with human capital and financial deepening. Emerg. Mark. Finance Trade, 45: 90102. DOI: $10.2753 /$ REE1540-496X450106

Ging, C.L., 2009. Foreign direct investment, pollution and economic growth: Evidence from Malaysia. Applied Econom., 41: 1709-1716. DOI: $10.1080 / 00036840701564376$

Elbeydi, K.M., A.M. Hamuda and V. Gazda, 2010. The relationship between export and economic growth in Libya Arab Jamahiriya. Theoretical Applied Econom., 17: 69-76.

Eryigit, M., 2012. The long run relationship between foreign direct investments, exports and gross domestic product: Panel data implications. Theoretical Applied Econom., 19: 71-84.

Furuoka, F., 2009. Exports and economic growth in ASEAN countries: Evidence from panel data analysis. IUP J. Applied Econom., 8: 7-16.

Feder, G. and G.T. O'Mara, 1982. On information and innovation diffusion: A bayesian approach. Am. J. Agric. Econom., 64: 145-147. DOI: $10.2307 / 1241186$ 
Liangshu, Q., 2007. The relationship between growth, total investment and inwards FDI: Evidence from time series data. Int. Rev. Applied Econom., 21: 119-133. DOI: 10.1080/02692170601035058

Mahadevan, R., 2007. New evidence on the export-led growth nexus: A case study of Malaysia. World Economy, 30: 1069-1083. DOI: 10.1111/j.14679701.2007.01030.x

Mishara, P.K., 2011. The dynamics of relationship between exports and economic growth in India. Int. J. Econom. Sci. Applied Res., 4: 53-70.

Mohamed, M., J.K. Singh and L. Chung-Yee, 2013. Impact of foreign direct investment and domestic investment on economic growth of Malaysia. Malaysian J. Econom. Stud., 50: 21-35.

Narayan, P.K., 2004. Reformulating critical values for the bounds f-statistics approach to cointegration: An application to the tourism demand model for fiji. Monash University, Clayton, Victoria.

Pesaran, H., Y. Shin and R. Smith, 2001. Bound testing approaches to the analysis of level relationships. J. Applied Econometr., 16: 289-326. DOI: 10.1002/jae.616
Sulaiman, M. and N. Saad, 2009. An analysis of export performance and economic growth of Malaysia using cointegration and error correction models. J. Dev. Areas, 43: 217-231. DOI: 10.1353/jda.0.0031

Shawa, M. and S. Yao, 2013. Causality relationship between foreign direct investment GDP growth and export for Tanzania. Int. J. Econom. Finance, 5: 1319. DOI: 10.5539/ijef.v5n9p13

Teodora, M.I. and S.R. Marinela, 2011. An investigation of longrun relationship between economic growth, investment and export in Romania. Econom. Sci. Series, 20: 316-621.

WTO, 2013. Annual report. World Trade Organization. www.wto.org/english/res./anrep13_e.pdf.

WB, 2013. The World Bank. www.worldbank.org/en/country/malaysia

Wei, H. and X. Wang, 2012. The trade structure of Chinese manufactured exports: 1999-2009. Am. J. Econ. Bus. Admin., 4: 197-206. DOI: 10.3844/ajebasp.2012.197.206 